\title{
A Lower Carboniferous two-stage extensional basin along the Avalon-Meguma terrane boundary: evidence from southeastern Isle Madame, Nova Scotia
}

\author{
ERIC R. FORCE ${ }^{1 *}$ AND SANDRA M. BARR ${ }^{2}$ \\ 1. Center for Mineral Resources, University of Arizona and U. S. Geological Survey, Tucson, Arizona, 85721, USA, \\ <ejforce@aol.com> \\ 2. Department of Geology, Acadia University, Wolfville, NS, B4P 2R6, Canada \\ * corresponding author
}

Date received: 22 December 2005 g Date accepted 07 March 2006

\begin{abstract}
Anomalously thick and coarse clastic sedimentary successions, including over $5000 \mathrm{~m}$ of conglomerate, are exposed on Isle Madame off the southern coast of Cape Breton Island. Two steeply to moderately dipping stratigraphic packages are recognized: one involving Horton and lower Windsor groups (Tournasian-Visean); the other involving upper Windsor and Mabou (Visean-Namurian) groups. Also anomalous on Isle Madame are three long narrow belts of "basement" rocks, together with voluminous chloritic microbreccia and minor semi-ductile mylonite, which are separated from the conglomerate-dominated successions by faults. The angular relations between the cataclastic rocks and the conglomerate units, combined with the presence of cataclasite clasts in the conglomerate units and evidence of dip-slip faults within the basin, suggest an extensional setting, where listric normal faults outline detachment allochthons. Allochthon geometry requires two stages of extension, the older stage completed in early Windsor Group time and including most of the island, and the more local younger stage completed in Mabou Group time. Domino-style upper-plate faulting in the younger stage locally repeated the older detachment relation of basement and conglomerate to form the observed narrow belts. Re-rotation of older successions in the younger stage also locally overturned the Horton Group. These features developed within a broad zone of Carboniferous dextral transcurrent faulting between already-docked Avalon and Meguma terranes. Sites of transpression and transtension alternated along the Cobequid-Chedabucto fault zone that separated these terranes. The earlier extensional features in Isle Madame likely represent the northern headwall and associated clastic debris of a pull-apart or other type of transtensional basin developed along part of this fault zone that had become listric; they were repeated and exposed by being up-ended in the second stage of extension, also on listric faults. The two-stage history on Isle Madame exposes the deeper parts of one of the Horton-age extensional basins of the Maritimes, others of which have been described as half-grabens based on their shallower exposures.
\end{abstract}

\section{RÉSUMÉ}

Des successions sédimentaires clastiques exceptionnellement épaisses et grossières, dont plus de 5000 mètres de conglomérat, affleurent sur l'île Madame au large de la côte méridionale de l'île du Cap-Breton. On distingue deux ensembles stratigraphiques fortement à modérément inclinés : l'un comprenant le groupe de Horton et la partie inférieure du groupe de Windsor (Tournaisien-Viséen); l'autre comprenant la partie supérieure du groupe de Windsor et le groupe de Mabou (Viséen-Namurien). On relève un autre ensemble anomal sur l'île Madame : trois longues ceintures étroites de roches « du socle », ainsi que de volumineuses microbrèches chloriteuses et une quantité modeste de mylonite semi-ductile, séparées des successions à prédominance de conglomérat par des failles. Les rapports angulaires entre les roches cataclastiques et les unités de conglomérat, conjugués à la présence de clastes de cataclastite dans les unités de conglomérat et à la manifestation de failles à rejet incliné à l'intérieur du bassin, laissent supposer un milieu de distension, où des failles normales listriques délimitent des terrains allochtones de décollement. La géométrie des terrains allochtones suppose deux stades de distension, le stade le plus ancien ayant pris fin au début de la période du groupe de Windsor et incluant la majeure partie de l'île, et un stade récent plus local ayant pris fin au cours de l'époque du groupe de Mabou. La formation de failles en chaîne dans la lèvre supérieure au cours du stade plus récent a répété par endroits l'ancienne géométrie du socle et du conglomérat, reproduite par des décollements, pour former les ceintures étroites observées. Une nouvelle rotation des successions anciennes au cours du stade récent a par 
ailleurs renversé localement les successions du groupe de Horton. Ces particularités se sont manifestées à l'intérieur d'une vaste zone de jeux de failles de coulissage dextres du Carbonifère entre les terranes déjà ancrés d'Avalon et de Meguma. Les sites de transpression et de transtension ont alterné le long de la zone faillée de Cobequid-Chedabucto qui sépare ces terranes. Les indices d'extension plus précoces sur l'île Madame représentent vraisemblablement le mur d'amont septentrional et les débris clastiques associés d'un bassin de transtension à écartement ou d'un autre type s'étant développé le long d'une partie de la zone faillée qui est devenue listrique; ils ont été répétés et en sont venus à affleurer après un culbutage au cours du deuxième stade d'extension, ayant également affecté les failles listriques. Le passé en deux stades de l'île Madame met à découvert des parties plus profondes de l'un des bassins d'extension des Maritimes de la période de Horton, dont les autres parties ont été décrites en tant que demi-grabens d'après leurs affleurements plus proches de la surface.

[Traduit par la redaction]

\section{INTRODUCTION}

Most of Isle Madame and adjacent Petit-de-Grat Island (subsequently referred to collectively as Isle Madame) on the southern tip of Cape Breton Island, Nova Scotia (Fig. 1), consist of Carboniferous sedimentary rocks and pre-Carboniferous "basement" units (Weeks 1954; White and Barr 1998; Giles et al. in press). Geological relationships on Isle Madame are unlike those elsewhere in the region in that the pre-Carboniferous rocks occur in elongate, fault-bounded belts separated by thick, steeply dipping, conglomerate-dominated Carboniferous suc- cessions (Fig. 2). The purpose of this study is to investigate the significance of these conglomerate units and their relation to the older rocks in terms of both local and regional structural settings, and to suggest a crustal extension model for their development.

The two-fold division of the rocks of Isle Madame into basement and conglomerate-dominated sedimentary successions was recognized by previous workers in the area, beginning with Fletcher (1881), who interpreted the basement rocks as Precambrian and the sedimentary rocks as Devonian. Weeks $(1954,1964)$ included the basement rocks in the Precambrian

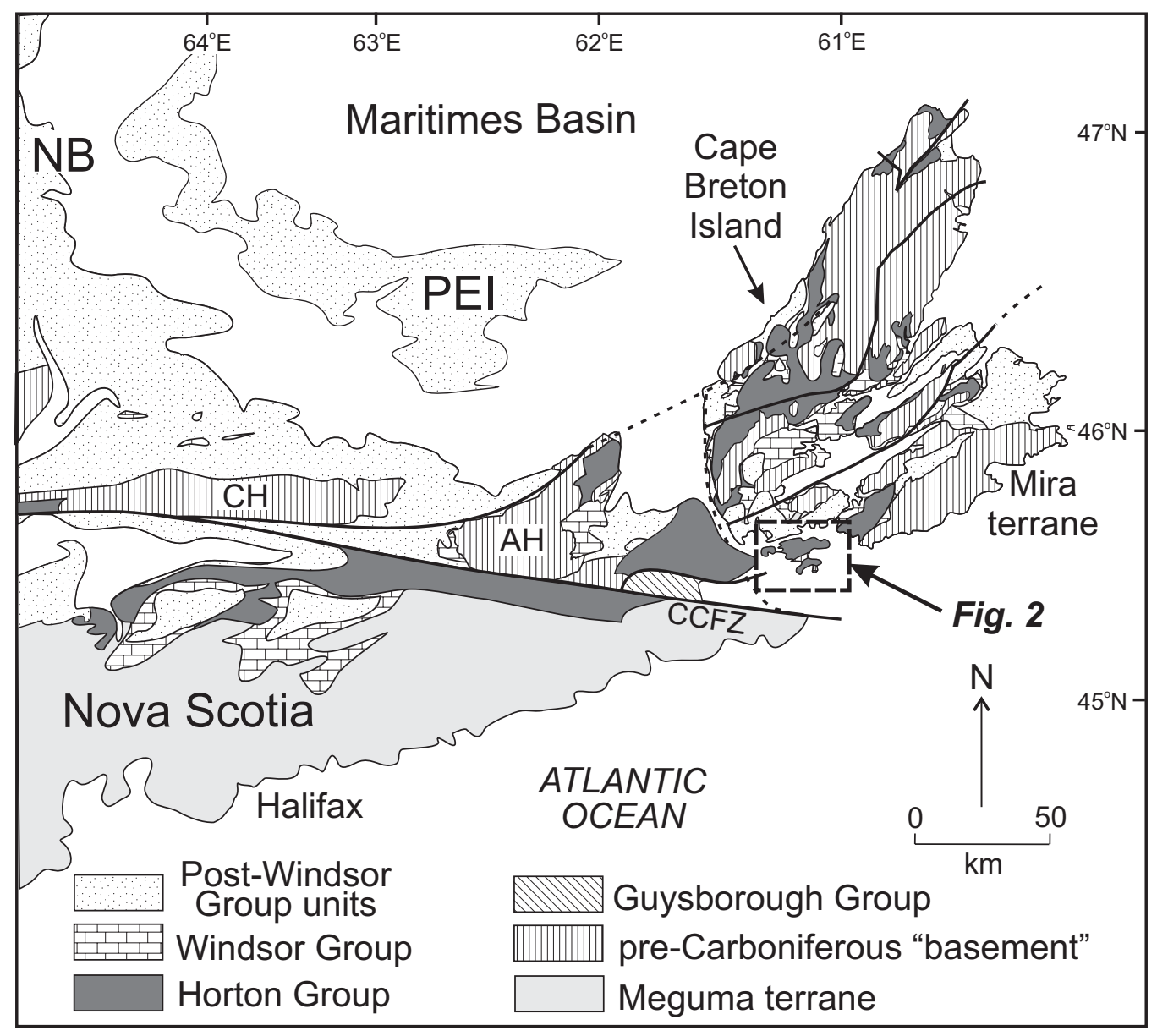

Fig. 1 Simplified geological map of Cape Breton Island and adjacent parts of northern mainland Nova Scotia, New Brunswick (NB), and Prince Edward Island (PEI), showing the location of the Isle Madame area. Cobequid Highlands (CH), Antigonish Highlands (AH), and Mira terrane are all part of the Avalon terrane. Solid and dashed lines are faults. CCFZ, Cobequid-Chedabucto Fault Zone. Map is modified from Reynolds et al. (2004). 
Fourchu Group of southeastern Cape Breton Island, although he acknowledged their unusual and apparently exotic character. He described the rocks as fine breccia and tuff, or greywacke composed of volcanic material, and mentioned that they have been granitized adjacent to "rhyolite intrusions". Barr et al. (1982) reported petrographic and chemical data from the Petit-de-Grat pluton, one of the "rhyolite intrusions" of Weeks (1954), located on the southeastern tip of Petit-de-Grat Island. Cormier (1980) reported a Rb-Sr isochron age of $357 \pm$ $11 \mathrm{Ma}$ for the pluton, and Keppie (1982) mentioned a ${ }^{40} \mathrm{Ar} /{ }^{39} \mathrm{Ar}$ amphibole cooling age of about $391 \mathrm{Ma}$ for amphibolite from Green Island, located offshore from Isle Madame (Fig. 2). Barr et al. (1992) noted the varied metamorphic and mylonitic rocks in the basement blocks on Isle Madame and Green Island, and suggested that they were derived from the Meguma terrane. White and Barr $(1998,1999)$ included the metamorphic rocks in a map unit termed the Chedabucto fault complex, and assigned the adjacent mainly conglomeratic rocks to the midDevonian Glenkeen Formation. Subsequent mapping and palynology resulted in reassignment of some of the Glenkeen Formation of White and Barr $(1998,1999)$ to the Horton Group (Giles et al. in press).
However, in spite of these advances in the understanding of the distribution of Carboniferous and pre-Carboniferous rock units and refinement of their ages, the reason for the fault-bounded belts of metamorphic rocks and Glenkeen Formation and the atypical abundance of conglomerate in the Carboniferous units remained uncertain. The present study is an attempt to resolve these enigmas.

\section{REGIONAL DEVONIAN AND CARBONIFEROUS GEOLOGY}

The Maritimes Basin was initiated following the Acadian orogeny (ca. 400-390 Ma; Hicks et al. 1999), apparently as a number of half-graben depocentres related to regional extension (e.g., Belt 1968; Hamblin and Rust 1995; Calder 1998; Waldron et al. 2005), although the mechanism of basin formation is uncertain (e.g., Bradley 1982; McCutcheon and Robinson 1987; Murphy and Keppie 1998; Lynch and Tremblay 1994; Lynch 2001). Lynch and Tremblay (1994) and Lynch (2001) suggested that basin development included a Late Devonian regional detachment, which they termed the Margaree detachment.

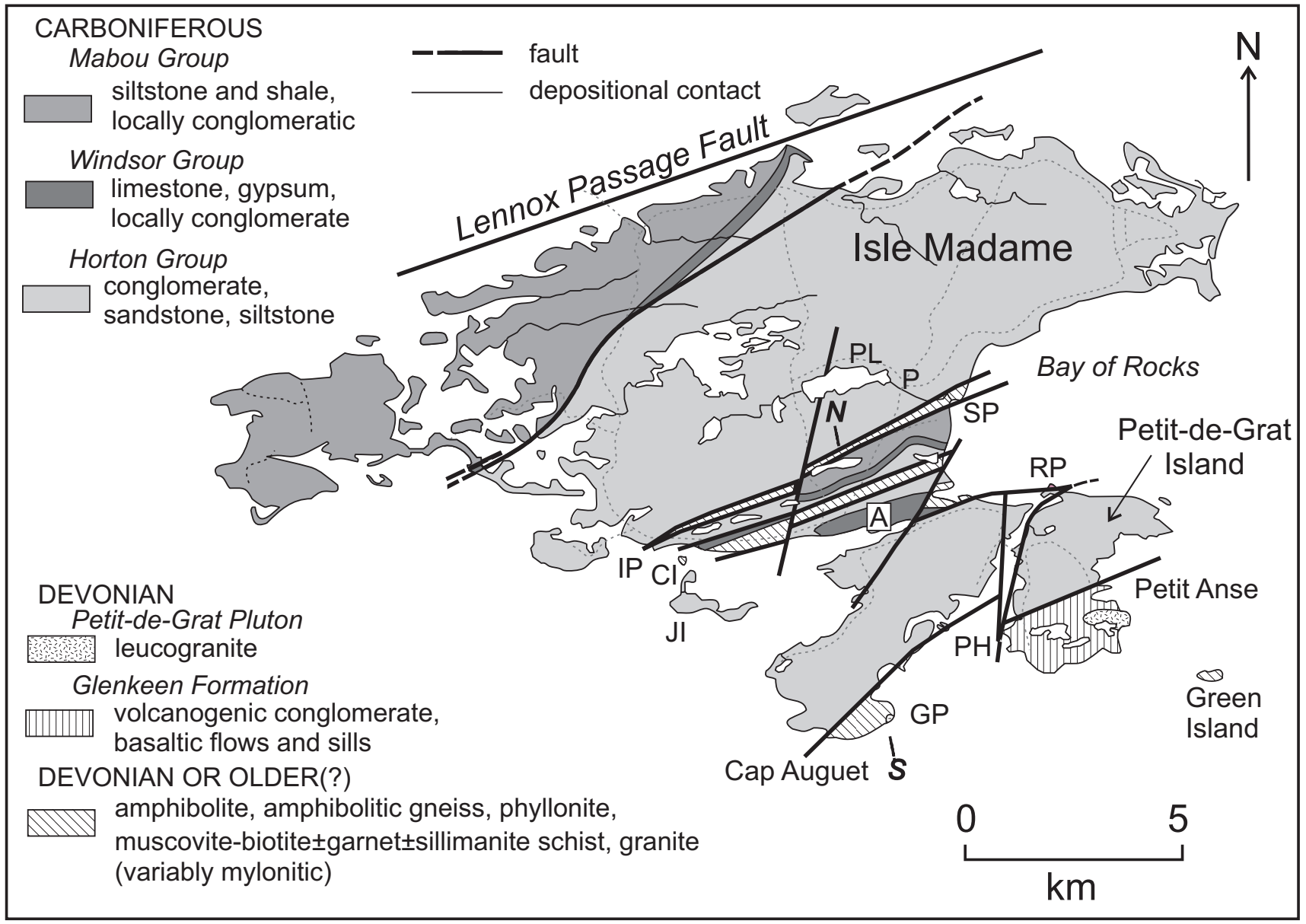

Fig. 2 Simplified geological map of the Isle Madame-Petit-de-Grat area (after Giles et al. in press and this study). Abbreviated localities: A, village of Arichat; IP, Irish Point; CI, Crid Islands; GP, Guet Point; JI, Jerseyman island; P, Pondville; PH, Petit-de-Grat Harbour; PL, Pottie Lake; RP, Rantellau Point; SP, Shaw Point. N-S is the location of the cross-section in Fig. 12. 
The mid to late Devonian part of the basin fill is exposed only at scattered locations in Cape Breton Island and northern mainland Nova Scotia, and generally consists of interbedded volcanic and sedimentary rocks, as exemplified by the Glenkeen Formation in the Guysborough area (Cormier et al. 1995; White and Barr 1999) and the Fisset Brook Formation in Cape Breton Island (e.g., Dunning et al. 2002). These older units are unconformably to conformably overlain by the more voluminous and widespread younger and dominantly sedimentary units of the basin. The latter units are the mainly nonmarine Horton Group (latest Devonian to Tournaisian), overlain unconformably by the shallow marine and nonmarine Windsor Group (middle Visean) and the nonmarine Mabou, Cumberland, and Pictou groups (late Visean to early Permian).

Although volcanic rocks occur mainly in the earliest part of the basin fill, they also occur higher in the succession. Gabbroic plutons and related minor basalt flows in southern Cape Breton Island have been dated at $339 \pm 2 \mathrm{Ma}(\mathrm{U}-\mathrm{Pb}$, zircon and baddeleyite; Barr et al. 1994), and appear to coincide with a regional unconformity between the Horton and Windsor groups (Reynolds et al. 2004). Locally in western Cape Breton Island and elsewhere, evidence for igneous activity during the time of Horton Group deposition is present in the form of mafic and felsic volcanic rocks and mafic dykes (e.g., Barr and Peterson 1998; Pe-Piper and Piper 1998; Dunning et al. 2002). Petrological characteristics of the volcanic rocks are generally consistent with eruption in a continental extensional setting (e.g., Barr et al. 1995; Barr and Peterson 1998; Pe-Piper and Piper 1998).

The Horton Group in the Maritimes Basin is commonly regarded as an intra-continental, fluvial to lacustrine basinfill succession that oversteps terrane boundaries (e.g., Calder 1998 and references therein). In mainland Nova Scotia, the basin-fill successions overlie rocks of both the Meguma and Avalon terranes, which were brought into juxtaposition during the Devonian along the Cobequid-Chedabucto fault zone (Fig. 1). Seismic profiles and sedimentary evidence indicate that Horton Group strata generally occupy local half grabens with varied polarity along this fault and other structures. The depositional succession in each Horton subbasin typically consists of (i) a thick basal coarse-grained alluvial succession that rests unconformably on older "basement" rock, overlain by (ii) a dark-grey, fine-grained lacustrine succession, which is overlain conformably to unconformably by (iii) an upper coarse- to fine-grained alluvial succession. These transtensional basins, however, were apparently separated by areas of transpression, and the Cobequid-Chedabucto fault zone itself was apparently a locus of both transpression and transtension, marked by alternating restraining and releasing bends (Webster et al. 1998; Reynolds et al. 2004; Waldron et al. 2005).

The Middle Carboniferous (middle Visean) Windsor Group unconformably to disconformably overlies the Horton Group in much of the Maritimes Basin. It formed when the restricted and hypersaline Windsor Sea flooded the Maritimes rift valleys from the east. The lower part of the Windsor Group is dominated by anhydrite, salt, gypsum, dolostone, and limestone, whereas the upper part consists of red siltstone and fine-grained sandstone with intercalated marine limestone, dolostone, and gypsum. Evaporites of the Windsor Group form diapiric structures in many areas (e.g., Boehner 1992; Durling et al. 1995; Calder 1998). The occurrence of an extensional detachment fault of possible basin-wide extent within the Windsor Group also has been suggested (the Ainslie Detachment of Lynch and Giles 1995). Following withdrawal of the Windsor Sea, a semiarid climate persisted through the late Visean when gray and red shale and siltstone, thin sandstone intercalations, and thin oolitic limestone of the Mabou Group were deposited in lakes. A profound change in basin evolution and paleoclimate occurred in the mid Namurian between deposition of the Mabou Group and the disconformably to unconformably overlying Cumberland Group (Calder 1998). Dextral motion between the Avalon and Meguma terranes along the Cobequid-Chedabucto fault system is inferred to have caused basin inversion and deformed to varying degrees the older basin fill (Calder 1998). Following this event, the dominant depositional systems in the Maritimes Basin changed from lacustrine to fluvial, represented by sandstone and coal of the Upper Carboniferous Cumberland Group. In the Late Carboniferous to Early Permian, continental red beds of the Pictou Group were deposited widely across the Maritimes Basin during a period of regional thermal sag and increasing aridity. The final assembly of Pangaea brought regional basin inversion, and a pronounced unconformity is present between Upper Carboniferous-Permian and Triassic strata of the Mesozoic Fundy rift basin.

\section{GEOLOGY OF ISLE MADAME AREA}

\section{Metamorphic rocks}

Metamorphic "basement" rocks occur in three faultbounded belts (Fig. 2): a narrow belt extending $8 \mathrm{~km}$ from Shaw to Irish points, a $500 \mathrm{~m}$ wide swath extending northeast from Crid Island, and a belt of unknown width that includes the southern part of Isle Madame (Cape Auguet area) and probably extends to the east through Green Island. The Shaw Point-Irish Point belt consists of varied rocks with relationships obscured by faults and limited exposure, but including muscovite-biotite schist, brecciated basaltic rocks, and arkosic conglomerate with a mainly granitoid source. The larger and better exposed Arichat belt consists of higher grade rocks, including amphibolite, amphibole-biotite gneiss, muscovite-biotite schist, garnet-muscovite-sillimanite schist, and fine-grained to mylonitic leucogranite. Tight folds show strong mineral lineation parallel to fold axes. In the southern metamorphic belt, amphibolite and amphibolitic gneiss with lit-par-lit leucogranite sheets, similar to some components in the Arichat belt, outcrop on Green Island (Fig. 3). Similar rocks also occur north of Guet Point on southern Isle Madame, but most of the Cap Auguet-Guet Point area consists of muscovite-biotite schist and lower grade muscovite-biotite phyllonite. 
Also present is a small body of mylonitic leucogranite, similar to the Petit-de-Grat granite described below.

Hornblende from layered amphibolite on Green Island previously yielded a ${ }^{40} \mathrm{Ar} /{ }^{39} \mathrm{Ar}$ plateau age of ca. $391 \mathrm{Ma}$ (Keppie 1982), which provides a minimum age for the metamorphic units. These fault-bounded slivers may have originated along the Avalon-Meguma terrane boundary, as previously suggested by Barr et al. (1992) and White and Barr (1999) based on petrological similarities to rocks in faulted slivers in the Guysborough area and elsewhere to the west. However, whether they were derived originally from an Avalon or a Meguma source is unknown.

\section{Glenkeen Formation}

In its type area near Guysborough, the Middle Devonian Glenkeen Formation consists mainly of conglomerate, with minor subarkose, siltstone, tuffaceous sandstone, tuff, and basaltic flows. The formation is part of the Guysborough Group, the age of which is constrained to ca. $390 \mathrm{Ma}$ (Mid Devonian) by $\mathrm{U}-\mathrm{Pb}$ ages from rhyolitic tuff and cross-cutting gabbro (Cormier et al. 1995; White and Barr 1999). White and Barr $(1998,1999)$ assigned conglomerate on southern Isle Madame and Petit-de-Grat Island to the Glenkeen Formation based on lithological similarity to the type area, including the presence of mafic volcanic rocks. Subsequent mapping (Giles et al. in press, and current study) resulted in a reduction in the extent of the unit to mainly southern Petit-de-Grat Island but the unit may also be present locally along the faulted margins of the metamorphic blocks in the Guet Point and Shaw Point areas (Fig. 2). On Petit-de-Grat Island, the Glenkeen Formation consists of conglomerate and mafic volcanic and hypabyssal rocks that are little metamorphosed, except in the contact aureole of the Petit-de-Grat Granite. In the latter area, pelitic units contain cordierite porphyroblasts. The granite also contains xenoliths that appear to have been derived from the Glenkeen Formation and associated hypabyssal mafic rocks.

Where mafic and granitic rocks are absent from the section, distinction between conglomerate in the Glenkeen Formation and conglomerate in the Carboniferous units described below is not easy. However, the younger conglomerate units generally contain a higher proportion of quartzite clasts relative to volcanic clasts. They also locally contain clasts derived from the metamorphic basement rocks; such clasts were not observed in the Glenkeen Formation.

\section{Petit-de-Grat Pluton}

The Petit-de-Grat Pluton forms the southeastern tip of Petit-de-Grat Island, and also occurs as dykes in the adjacent Glenkeen Formation. It consists of pink leucomonzogranite that was originally coarse grained but is now cataclased so that it appears fine grained in hand specimen. It consists of fragments of quartz, plagioclase, and K-feldspar and coarsegrained relict clusters of those minerals in a cataclastic matrix

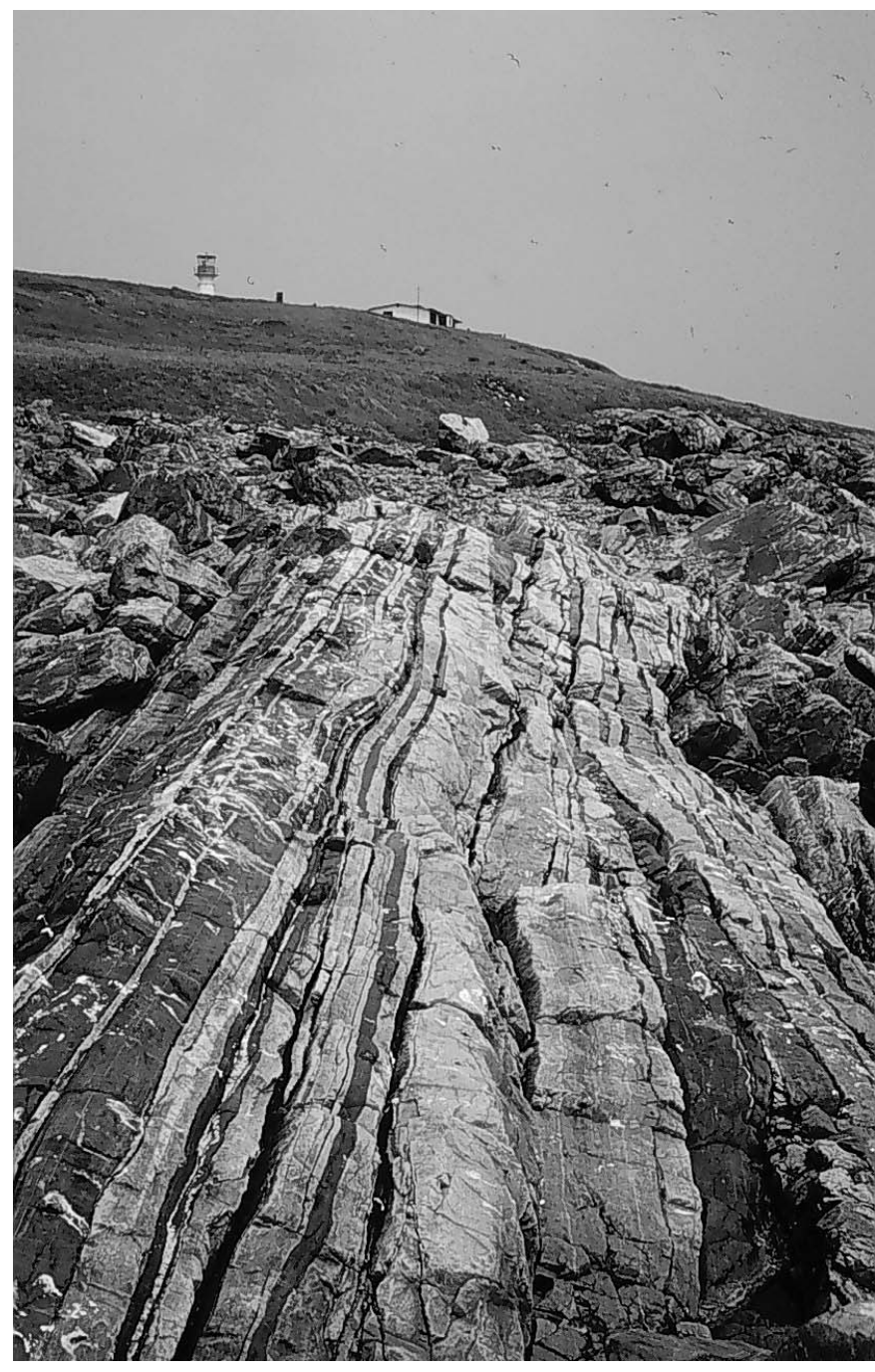

Fig. 3 Exposure on Green Island of metamorphic basement consisting of amphibolitic gneiss and amphibolite, with litpar-lit sheets of leucogranite.

of the same material. The granite yielded a U-Pb (zircon) age of $373 \pm 1 \mathrm{Ma}$ (White et al. 2003).

At Guet Point (Fig. 2) similar granite forms a small intrusion in metamorphic rocks, but it displays a mylonitic fabric that overprints the cataclastic fabric typical of the main pluton. Although somewhat similar in appearance, the $391 \mathrm{Ma}$ amphibole cooling age from Green Island indicates that the lit-par-lit granite sheets in the metamorphic rocks on Green Island and in the Arichat metamorphic belt are older, and not related to the ca. 373 Ma Petit-de-Grat Pluton.

\section{Carboniferous units}

Thick conglomerate-dominated successions dominate the geology of southern Isle Madame; most are part of the Horton Group (Tournasian) but some extend as high as the Mabou Group (Visean-Namurian). Typical stratigraphic sections are illustrated in Fig. 4; thicknesses shown are minima because the 


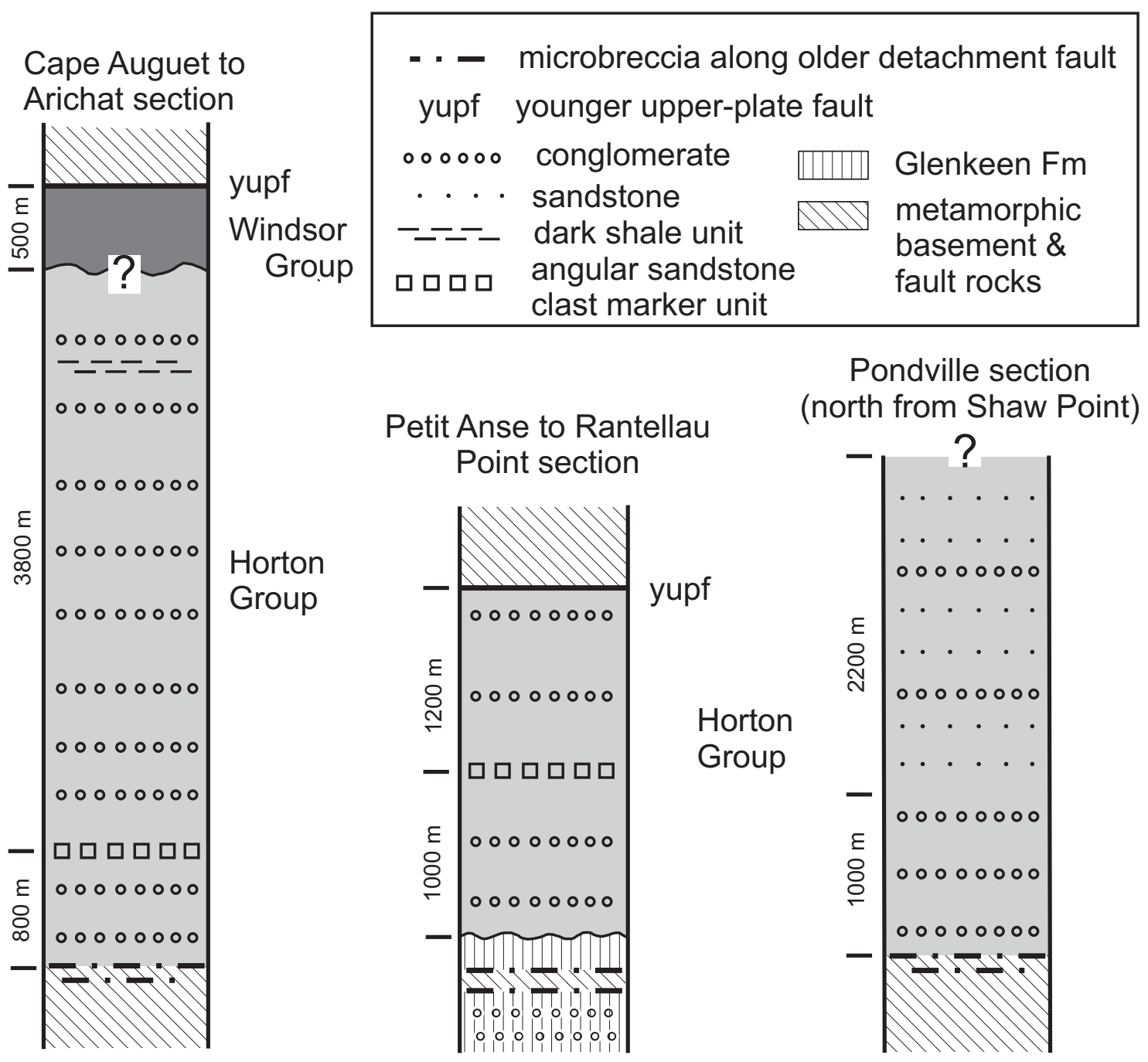

Fig. 4 Approximate stratigraphic sections between Cape Auguet and Arichat, Petit Anse and Rantellau Point, and north from the Shaw Point basement sliver. The rocks are generally steeply dipping and young to the north. The angular sandstone-clast conglomerate is a marker bed between the first two stratigraphic sections and is illustrated in Fig. 5 .

successions are fault bounded. Conglomerate predominates in these successions, with a total conglomerate thickness of more than $5000 \mathrm{~m}$, although precise measurement is not possible due to extensive outcrop gaps coupled with numerous minor faults and folds. Also, the total thickness of the succession depends on correlations between fault-bounded blocks containing coarse-grained successions with few markers.

The successions shown in Fig. 4 are generally steeply dipping and everywhere young to the north. Induration varies from high to moderate depending on age and tectonic environment as described below. Quartz-hematite and quartz-carbonate veins are abundant; their orientations were not measured but no consistency was noted in the field. Finer grained interbeds and intervals, generally of maroon to gray-green sandstone and sandy argillite, commonly show cleavage and/or kink-folds, which are thought to be later features than those described here. Carboniferous plant fossils, spores, and pollen are only sparingly present in such beds (P. Giles, personal communication, 2002).
The most common clast assemblage in the conglomerate units is polymictic with sedimentary and volcanic clasts most abundant, locally with subordinate fine-grained pink granite clasts and phyllitic clasts. Clasts are generally subangular and poorly sorted. These basement-derived, oligomictic, and well-rounded or framework-supported conglomerate units have promise of being traced and/or correlated from section to section (Fig. 4), although such correlation is typically problematic in conglomerate. Clast size ranges from granule up to boulder. Clast imbrication was seldom observed, and transport directions are therefore unknown. Alluvial fans were probably the main depositional environment, or perhaps fandeltas with marine influences. A few beds may be landslide breccia, i.e. monolithologic angular stratabound breccia (e.g., Yarnold and Lombard 1989). The provenance of some of the clasts was addressed by Boucot et al. (2006), who showed that Avalon-related faunal assemblages are present in clasts from both Horton Group and younger conglomerate, implying derivation from the north. 
Because the Carboniferous successions on Isle Madame are so much coarser and otherwise unlike coeval successions elsewhere in the region, it is likely that the sedimentary successions on Isle Madame represent a separate sedimentary basin or distribution system. In view of the impossibility of demonstrating physical continuity with formational units named elsewhere, we use only group-rank formal stratigraphic terms in this paper.

The Horton Group, which appears to be more than $7000 \mathrm{~m}$ thick on Isle Madame (Fig. 4), consists mostly of highly indurated polymictic conglomerate with only one internal marker unit that we have discerned, containing angular blocks of sandstone (Fig. 4, 5). In the Cape Auguet-Arichat section, the Horton also contains an interval of gray sandstone and dark argillite, commonly in thin graded beds, which we informally call the dark shale unit (Fig. 4). It is shown as Tracadie Road Formation by Giles et al. (in press) and correlated with the medial part of the Horton Group in the region, which is typically finer grained than the rest of the group. However, a partial external mold of a bivalve was found in this unit on the south shore of inner Arichat Harbour, in low sea cliffs $5 \mathrm{~m}$ west of the L. Boudreau wharf. T. Dutro (2004, written communication) reported that he, John Pojeta and Serge Mamay, all of the U.S. National Museum, found the fossil to be very like Aviculopecten lyelliformis, a marine form. If so, this unit may be marine or near-marine, and may represent a facies that is absent outside the Isle Madame basin. On Jerseyman Island, the dark shale unit is apparently overlain by more conglomerate, which we correlate with a conglomeratic unit that fines upward to sandstone on islands in the Bay of Rocks north of Shaw Point (Fig. 4).

The Windsor Group on Isle Madame locally contains its typical marine evaporite component, but in most places on the island conglomerate is the predominant rock type. Locally a gneiss-clast conglomerate interbedded with calcarenite (Fig. 6) contains marine foraminifera (Peter Giles, personal communication, 2004). Gypsum beds and solution-collapse breccias are present in the Windsor Group in and east of Arichat. This succession of Windsor Group rocks may overlie the dark shale unit of the Horton Group in the Arichat area and conglomerate of the Horton Group near Jerseyman Island and, if so, the contact may be an unconformity; the exposures critical to resolve the question are lacking. A separate succession of Windsor Group transitional to Mabou Group in the Pondville area (Figs. 2, 4) consists of thick (at least $500 \mathrm{~m}$ ) conglomerate with sedimentary clasts; it includes one finer grained laminated interval, and is a little less indurated than most Windsor Group conglomerate. Below we make the case that this upper Windsor to Mabou Group succession has a different tectonic history than the Horton to lower Windsor Group succession.

\section{Fault rocks}

The metamorphic basement and/or Glenkeen Formation are everywhere separated from the Carboniferous conglomerate-dominated sedimentary successions by faults, marked

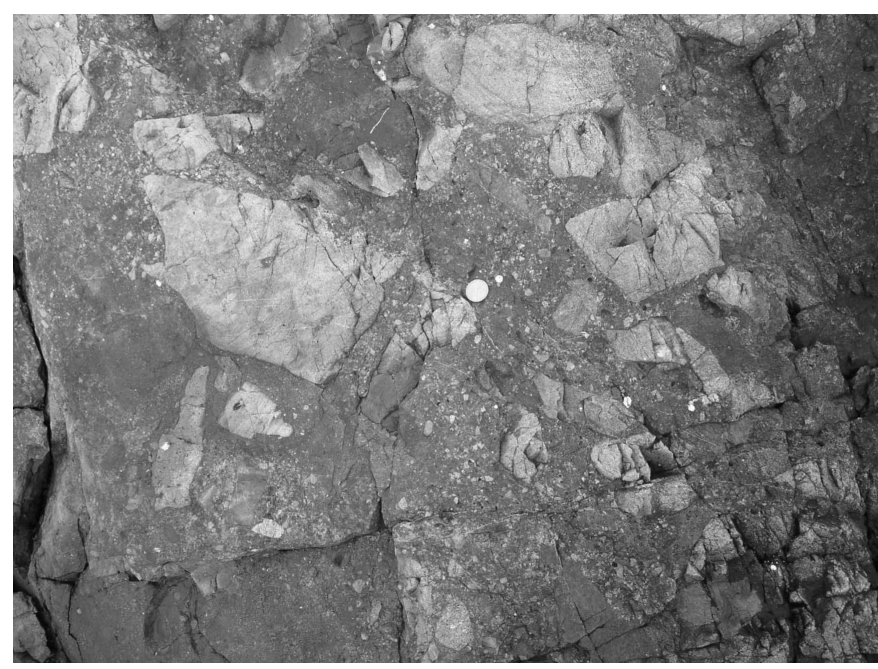

Fig. 5 Angular sandstone-block conglomerate in Horton Group, southern Petit-de-Grat Harbour.

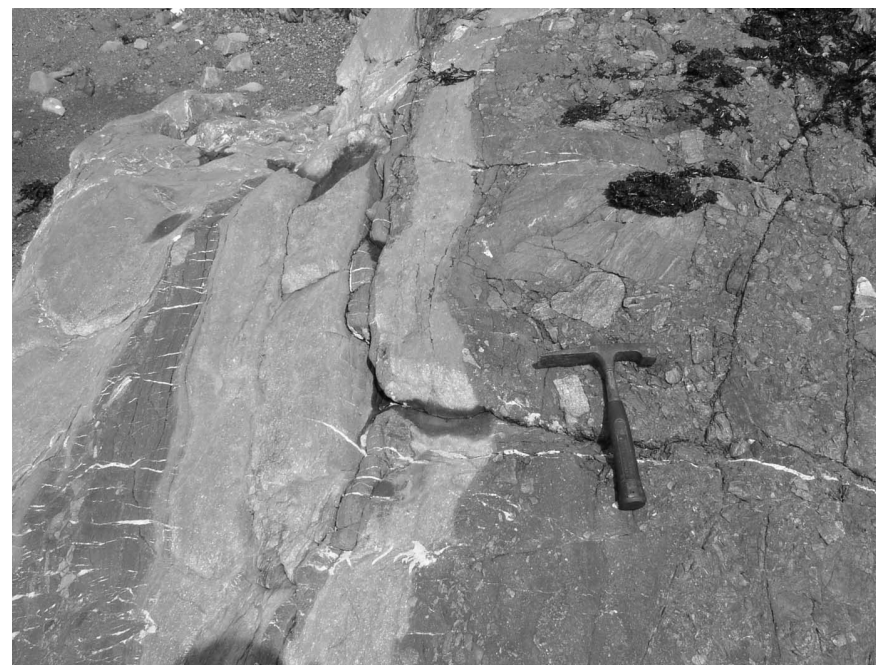

Fig. 6 Basement-clast conglomerate with calcarenite interbeds (extending across the left side of the figure), lower Windsor Group, Irish Point.

by chloritic breccia and microbreccia developed within both metamorphic basement and Glenkeen Formation. These zones contain discontinuous patches and dykelets of granitic material (derived from Petit-de-Grat Granite?). Locally, the fault rock shows traces of basement types not present nearby, such as gneiss in fault rock on Glenkeen Formation, or Glenkeen Formation in fault rock on basement gneiss.

The thicknesses of fault-rock septa between basement and conglomerate vary considerably, from as little as $10 \mathrm{~m}$ (Fig. 7) to probably $100 \mathrm{~m}$, depending on where gradational boundaries between basement and fault rock are drawn. More conventional, apparently younger, faults also separate the preCarboniferous and Carboniferous rocks locally, as described below.

The fault rocks look similar at both outcrop and microscopic scale due to the fractal nature of the breccia textures (Fig. 8a, b). Textural and vein relations locally suggest overprinting of more 


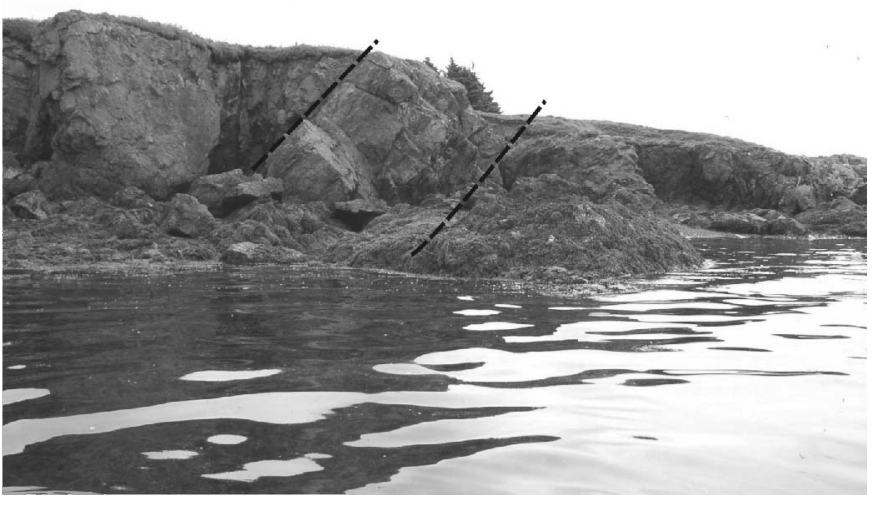

Fig. 7 Fault rock (outlined) dipping north, separating gneissic basement (to right) from Horton conglomerate (to left) on the Crid Islands. Photo was taken looking northeast.

ductile deeper assemblages by brittle shallow ones. Overall, features observed at the microscopic scale are consistent with the inferred map-scale feature of juxtaposition of different crustal levels as described below. Epidote and chlorite are the most typical syntectonic minerals in the fault rock. Specular hematite, albite, adularia, and quartz fill voids and form veins, and also occur as granulated fragments in the groundmass. Iron sulphide is present locally.

Where slickenlines are preserved in fault rock, about half are steeply plunging, suggesting dip-slip motion (Fig. 9a). These slickenlines are similar to those in the sedimentary units (Fig. 9b). The remaining slickenlines measured in fault rock are more gently plunging, suggesting a transcurrent component of motion in fault rocks only. Evidence for relative ages of the slickenlines was not observed.

\section{Structural relations among units}

The "basement" rocks, including the Glenkeen Formation and the $373 \mathrm{Ma}$ Petit-de-Grat Granite, are parental to the fault rocks, which developed from "basement" along its northern margins (Fig. 2). Carboniferous conglomerate in contact with the fault rocks contains clasts of fault rock (e.g., Fig. 10), but the fault rock cuts bedding in the conglomerate-dominated sedimentary successions at a high angle, suggesting that they developed concurrently. Thus the fault rock systematically juxtaposes rock assemblages representing different crustal levels. The difference between fault rocks and sedimentary rocks in slickenline orientations (Fig. $9 \mathrm{a}, \mathrm{b}$ ) suggests that fault rocks were subject to some transcurrent motion, whereas the sedimentary rocks were not. Almost all of the contacts are steeply dipping, however, requiring a somewhat unusual evolution of features.

Other structural features of the area (Fig. 2) include faults along the southern margins of basement belts, a fault east of
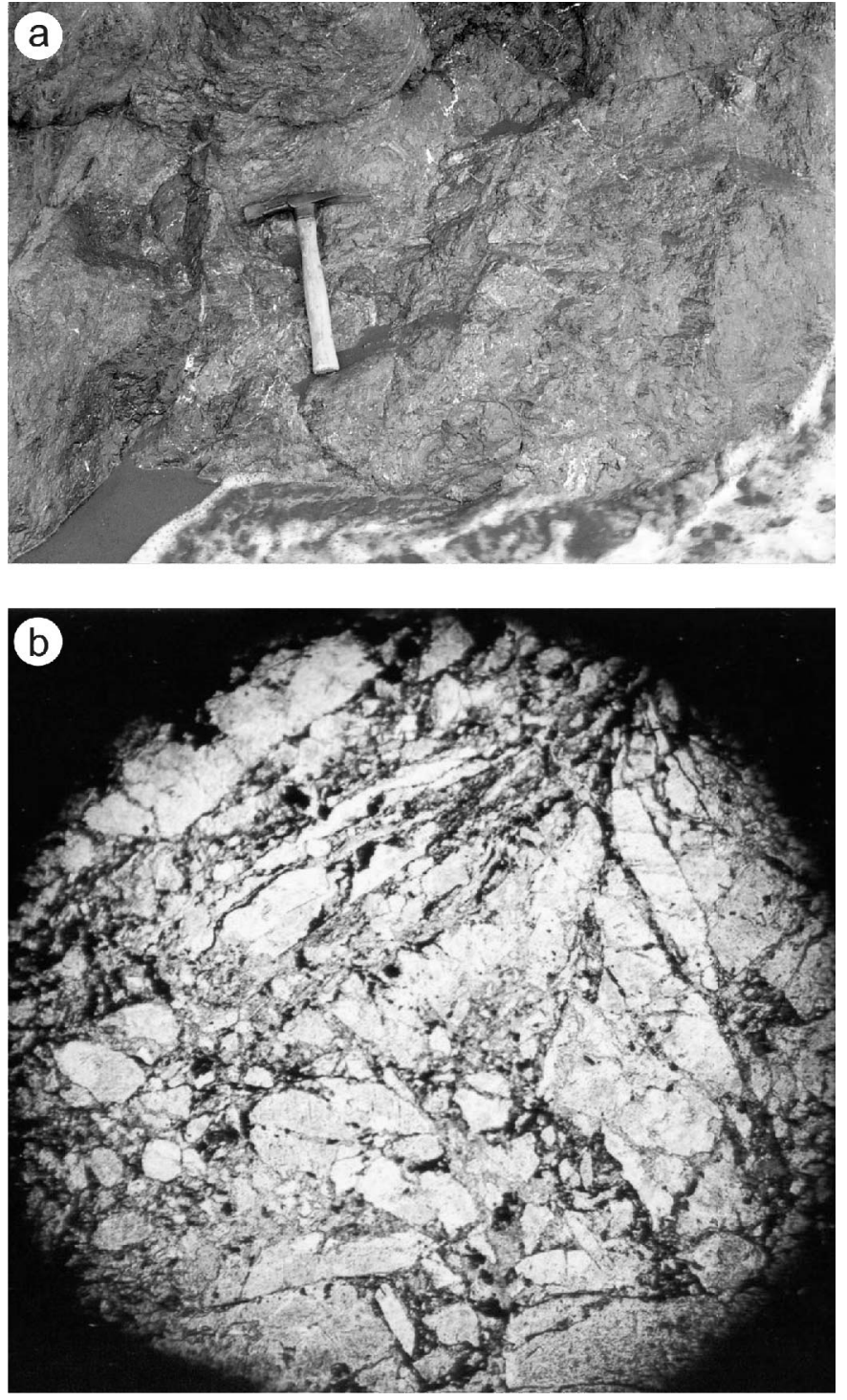

Fig. 8 (a) Outcrop of typical fault rock at Shaw Point. (b) Photomicrograph of fault rock from the same area. Field of view $3.5 \mathrm{~mm}$

Arichat that offsets a basement belt, and an oblique exposure through a tilted graben in the harbour of Petit-de-Grat, as well as a number of other minor faults (Giles et al. in press) omitted for clarity.

\section{EXTENSIONAL MODEL}

Certain aspects of these relations fit an extensional model in which the conglomerate units are syn-extensional deposits:

1. The synchronous development of faults and conglomerate units, as evidenced by clasts of fault rock in conglomerate.

2. The juxtaposition of brittle and ductile deformation structures and of rocks of widely different metamorphic grades, suggesting juxtaposition of different crustal levels. 

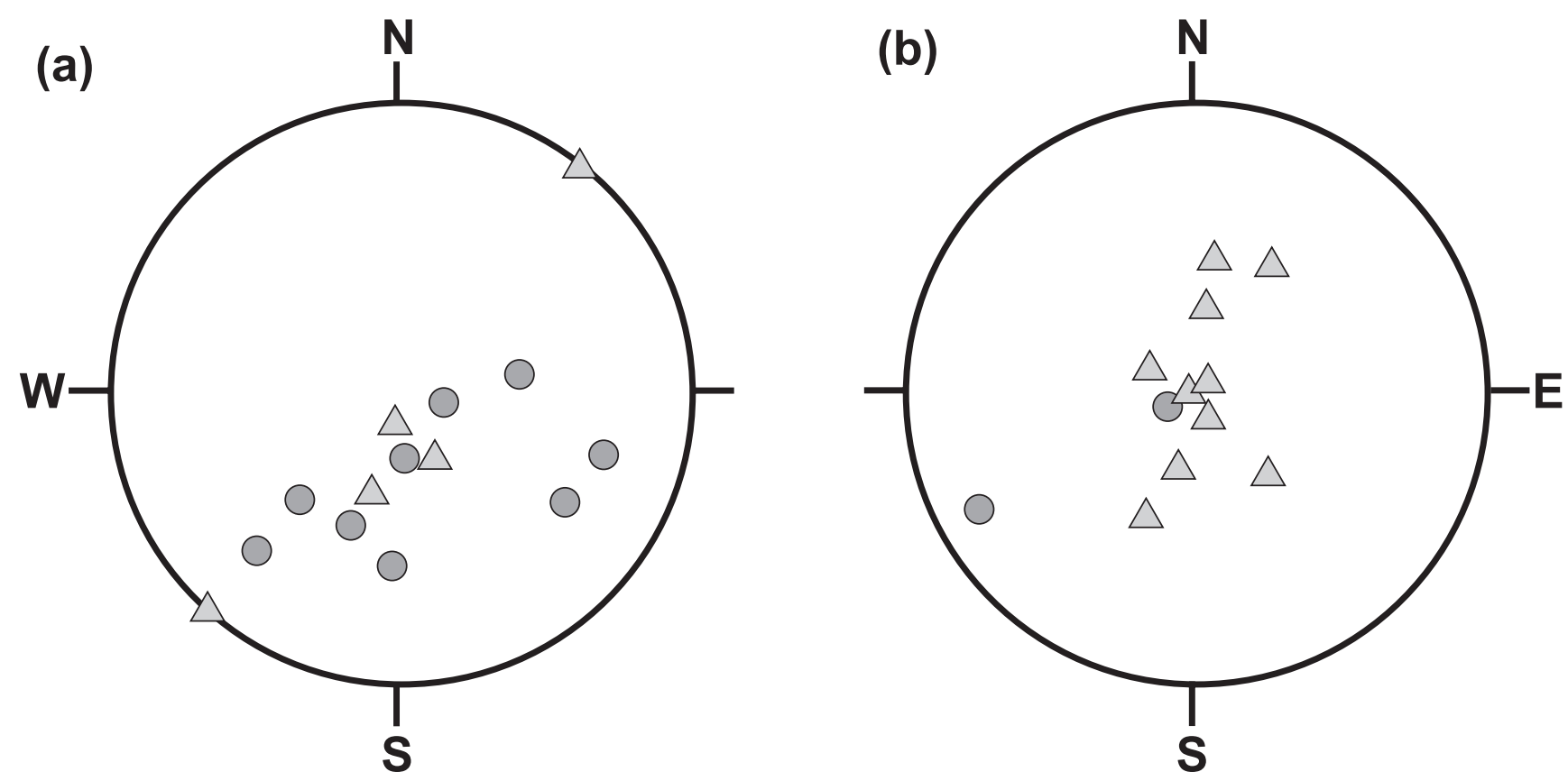

Fig. 9 Stereonets showing trend and plunge of slickenlines (circles) measured in (a) fault rock and (b) sedimentary units on Isle Madame. Triangles in both (a) and (b) indicate down-dip slickenlines in their slickensided fault plane.

3. The systematic presence of thorough cataclasis of the older, deeper assemblage, particularly on its faulted boundaries.

4. The high angle between bedding in conglomerate and the cross-cutting faulted boundaries.

5. The thickness of conglomeratic debris.

6. The dip-slip motion on many fault boundaries.

In an extensional model, the elements fit together (Fig. 11) via listric detachment faults, with brittle-ductile transitions on the footwall from chloritic breccia to semi-ductile mylonite, fanning dips in syn-extensional upper-plate conglomerate units, domino-style upper-plate faults, and consistent angles of 50-70 degrees between detachments and bedding in conglomerate units (Seranne and Seguret 1987; Howard and John 1987; Lister and Davis 1989; Spencer and Reynolds 1989, 1991; Dickinson 1991). These angles preserve the original intersection of depositional bedding with fault scarps during transport along listric faults (i.e. the contacts originated as buttress unconformities). At the surface, relations and sedimentary patterns are those of half-grabens (see Leeder and Gawthorpe 1987).

However, some elements on Isle Madame differ from the model:

7. The dips of most of the faults are steep, unlike the gently dipping detachments described in the references cited above.

8. Considerable thicknesses of conglomerate-dominated successions are locally overturned

We think the simplest explanation of these anomalies is that the expected extensional-basin relations have been further disturbed in some areas by a second stage of extension. In the areas with only one stage of extension, dips of the conglomer- ate-dominated successions are to the north, and detachment faults would be gently dipping (if they were exposed). The implied detachment headwall is outside the study area, north of Isle Madame, and tectonic transport was north to south. The northward dip, probably gentle, of the detachment in the northern part of the study area suggests local footwall uplift.

In areas that experienced a second stage of extension, relations were rotated en masse (as shown in the inset of Fig. 11), causing older detachment faults to dip steeply north, and bedding in the Horton-lower Windsor Group succession to become overturned (but still younging north). Only the younger conglomerate-dominated succession within the second-stage allochthon dips north at moderate angles. Such overturning relations in extension have been observed elsewhere, especially where multi-stage (Hagstrum et al. 1987; Cox and Force, in press). We have considered the possibility that this second-stage event is not extensional but related to inversion; however, that model is not consistent with either the sediment provenance or dip angle of the younger succession. Indeed, it seems more likely that the second stage was related to secondary breakaway in a single extensional episode (e.g., Spencer and Reynolds 1989).

\section{TECTONIC INTERPRETATION FOR ISLE MADAME}

Figure 12 shows an interpretive $\mathrm{N}-\mathrm{S}$ cross-section of Isle Madame. Where a younger detachment episode has up-ended and repeated an older detachment system, the older detachment fault is exposed as the fault rocks on the northern edge of basement in each domino-style fault block of the younger 


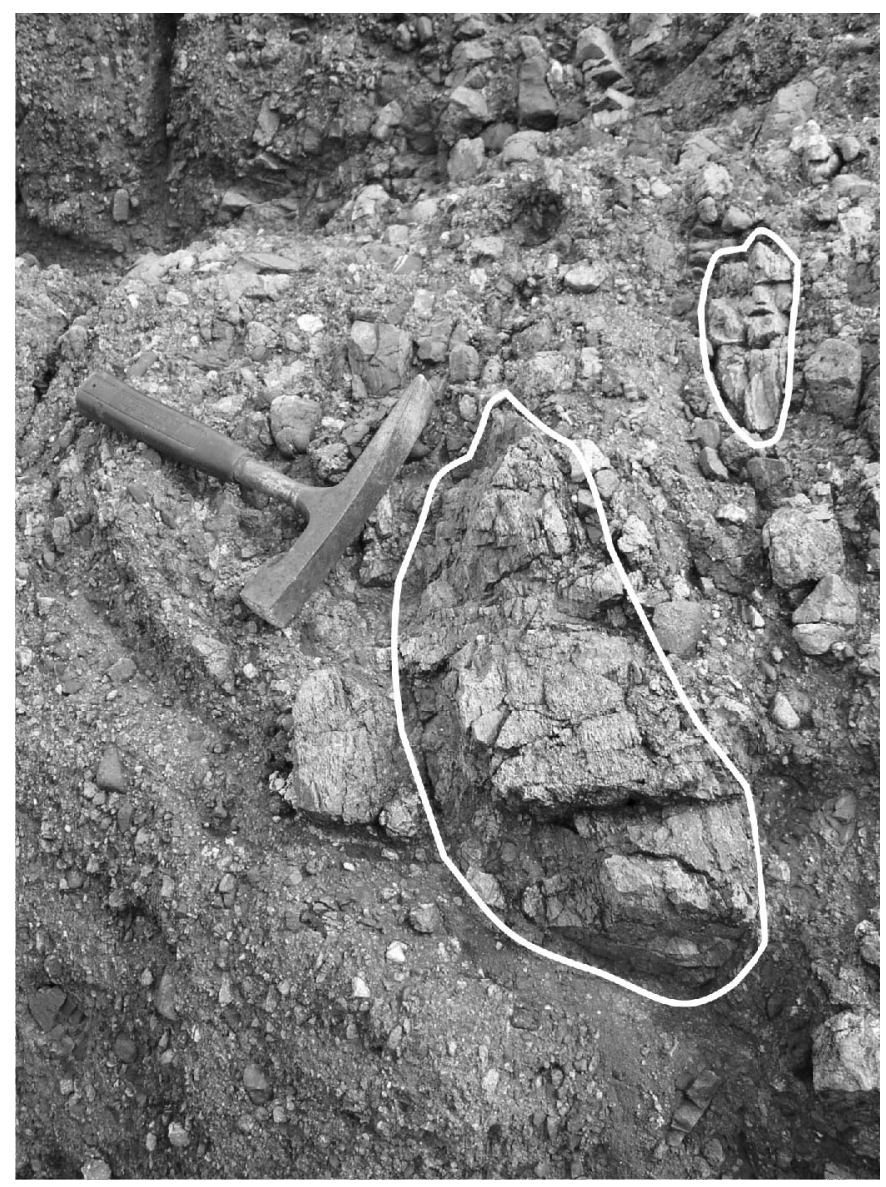

Fig. 10 Conglomerate of the Horton Group containing clasts of fault rock (outlined), Crid Islands.

system. This basement is, of course, the former lower plate of the older detachment system. The older syn-extensional deposits of Horton and lower Windsor groups have been overturned where they have been rotated more than a total of $90^{\circ}$ in the two stages. The younger upper Windsor and Mabou Group beds that formed during second-stage extension are not overturned, and outside the younger second-stage detachment allochthon, where the older beds have been tilted only once, they are not overturned either. All of the successions remain north younging.

The second-stage fault cutting the older detachment and basement, although unusual, is not unexpected or unique. Secondary breakaways by definition cut older detachments and may cut basement (Spencer and Reynolds 1989). Lister and Davis (1989) described single-stage fault-locus migrations that include younger faults stranding basement and older detachments on their upper plates.

The Crid Islands-Irish Point area (Fig. 2) presents an illuminating glimpse of the extensional relations we propose (Fig. 13). The Shaw Point-Irish Point and Arichat basement belts are both present, separated by two conglomerate-dominated successions. The older Horton and lower Windsor succession (Fig. 6) is vertical to slightly overturned, separated from younger gently dipping upper Windsor and Mabou succession

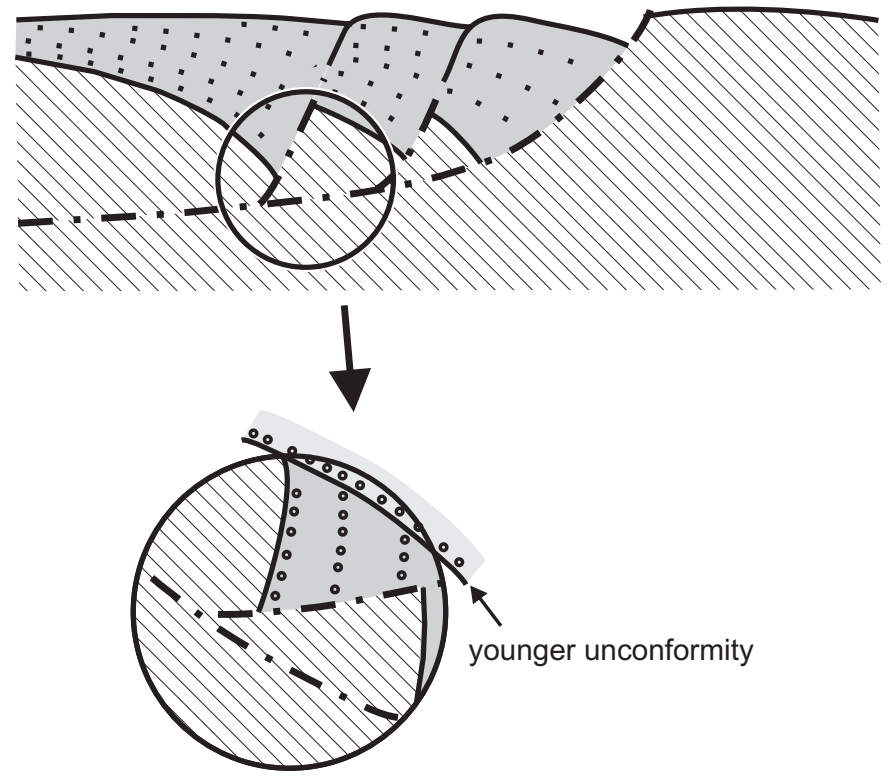

Fig. 11 Extensional model showing: typical relations of a listric fault that flattens and becomes more ductile on the lower plate with depth; fanning dips in syn-extensional coarse clastic sediments; typical intersection angles of these deposits with the listric fault; and domino-style faults in the upper plate. Inset below shows the result of further rotation in the same sense of a domain in the upper diagram, and adds a younger unconformity that records that further rotation.

by a younger upper-plate fault with gypsiferous gouge and an inferred unconformity. The older detachment is well exposed on the Crid Islands (Fig. 8) and the younger detachment at Irish Point.

This interpretation of extensional history divides Windsor Group deposition into two different tectonic settings, one during first-stage extension and one during the second stage. First stage extension was apparently Tournasian-Visean in age, and the second was Visean-Namurian. The expected unconformities between the two tectono-stratigraphic packages are poorly represented, because they largely occupy different fault blocks and/or different coastal sections. However, the block north of the Arichat basement belt seems to contain an unconformity between Horton and upper Windsor Group rocks (Figs. 13, 14).

In this view of the tectonic history of Isle Madame, the only basement block that is "rooted" is that between Shaw and Irish points. Aeromagnetic maps of the area (Geological Survey of Canada 1964) are consistent with this interpretation in showing that only this basement block has any magnetic expression.

Our interpretation of multi-stage extension is illustrated on a tectonic map of southeastern Isle Madame showing tilt domains (Fig. 14). The rocks that belong to an older tilt domain, where undisturbed by later extension, are characterized by 


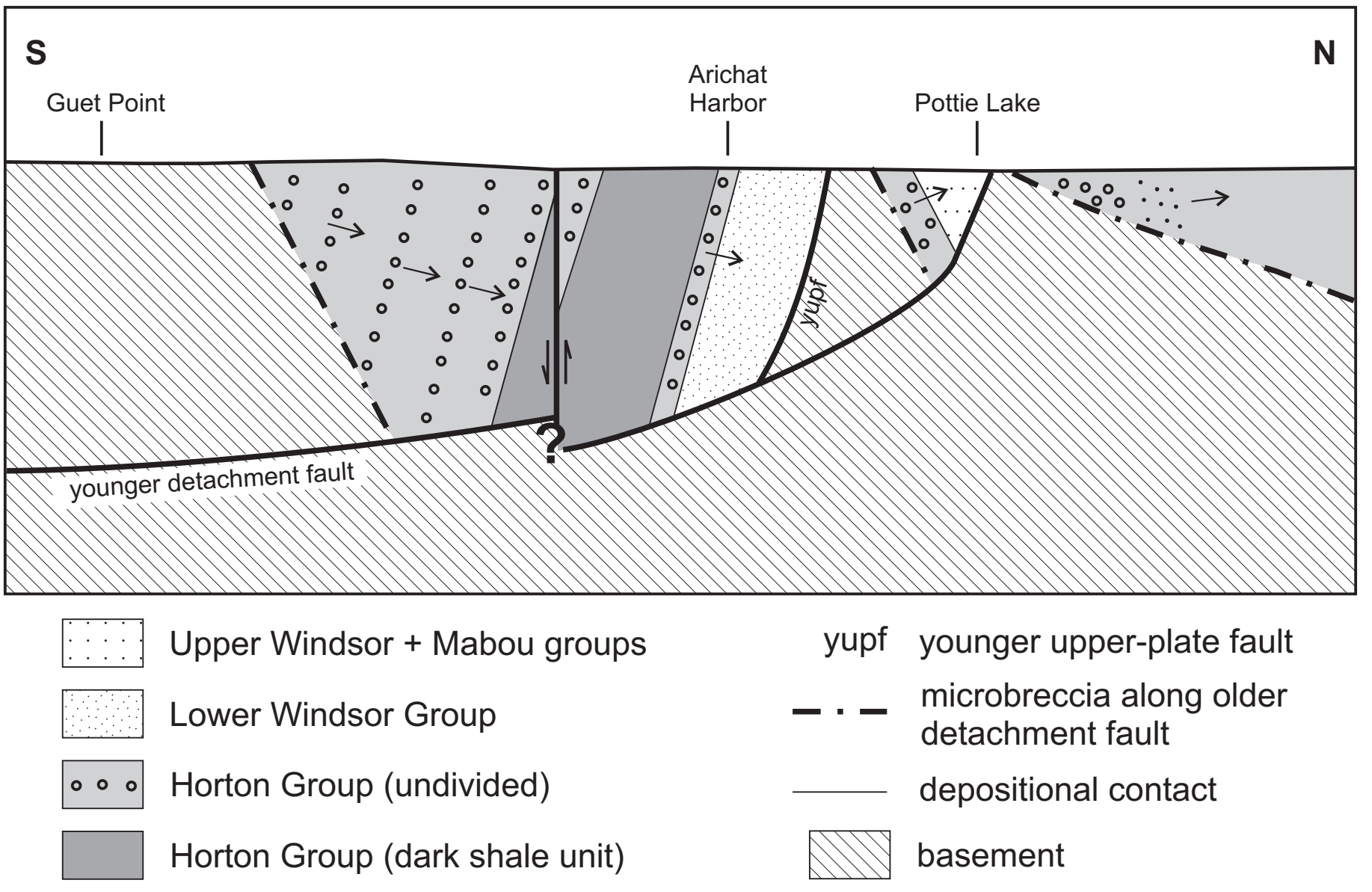

Fig. 12 Hypothesized cross-section from Guet Point (S) to Pottie Lake (N). Location of section is shown on Fig. 2. Apparent problems with retro-deformability of this section may result from: 1) the abundance of fault rock in the basement unit, which can deform somewhat plastically at the scale of this figure; 2) the fact that we may have missed some upper-plate faults, 3) the fact that transtensional origin implies movement in and out of the plane of the section not accounted for in the figure; and 4) the nature of syn-extensional deposits, which can vary in thickness and relations among blocks outlined by coeval faults. Arrows indicate younging direction.

north dips that average about $50^{\circ}$ in syn-extension deposits. In the younger Cap Auguet extensional allochthon, however, further movement has rotated these older deposits so that they are vertical to overturned. Deposits synchronous with younger extension in this area also dip north an average of about $50^{\circ}$.

Reconstruction of the second-stage extension in cross-section (Fig. 15) suggests that relations similar to those of metamorphic core complexes may have existed in the area (e.g., Davis 1987; Lister and Davis 1989), but were fragmented by second-stage faulting. The gentle northward dip of the firststage detachment suggests local footwall uplift. However, the scarcity of detachment-related ductile mylonite requires that uplift was not from great depth (e.g., Davis 1987; Davis et al. 2004). Second-stage extension itself may be a secondary breakaway as commonly observed where the footwall is uplifted (Spencer and Reynolds 1989).

\section{DISCUSSION}

Extensional basins of Horton Group age are reported elsewhere in the Maritime Provinces as described above, mostly as half-graben fills. Detachments faults have been mapped on Cape Breton Island north of the study area by Lynch (2001); his Ainslie detachment fault is younger and probably related to décollement along evaporite horizons, but his Margaree detachment could be coeval with the older detachment that we describe. The extent of the Margaree detachment system has not been documented to include southern Cape Breton Island, however, and correlation is as yet unwarranted.

The geologic setting of Nova Scotia during deposition of the Horton Group involved dextral movement of incoming Meguma terrane against already-docked Avalon terrane (Fig. 1). The association of transtensional basins with transcurrent 


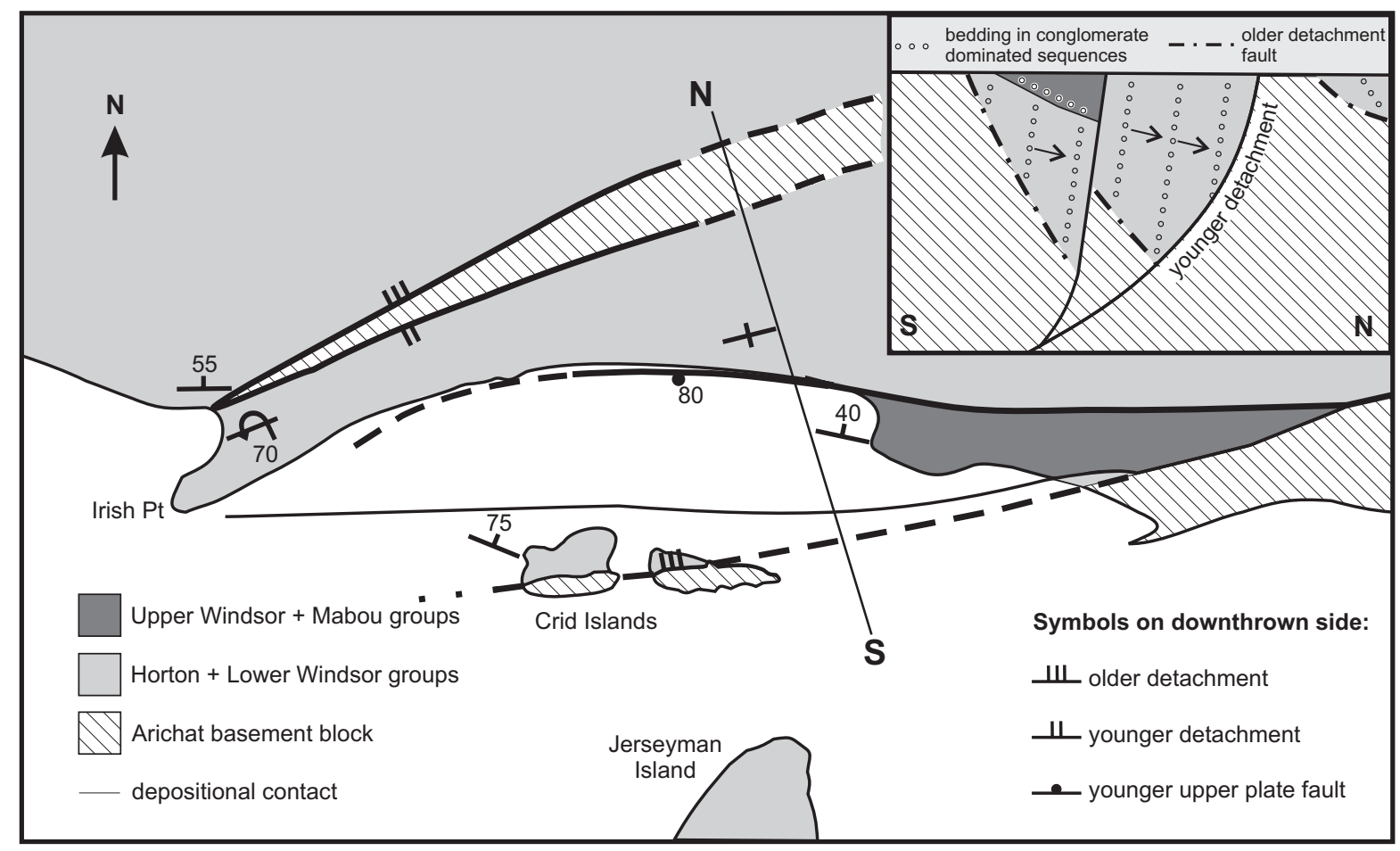

Fig. 13 Detailed map and cross-section (inset) of the Crid Islands area. Arrows on inset diagram indicate younging direction.

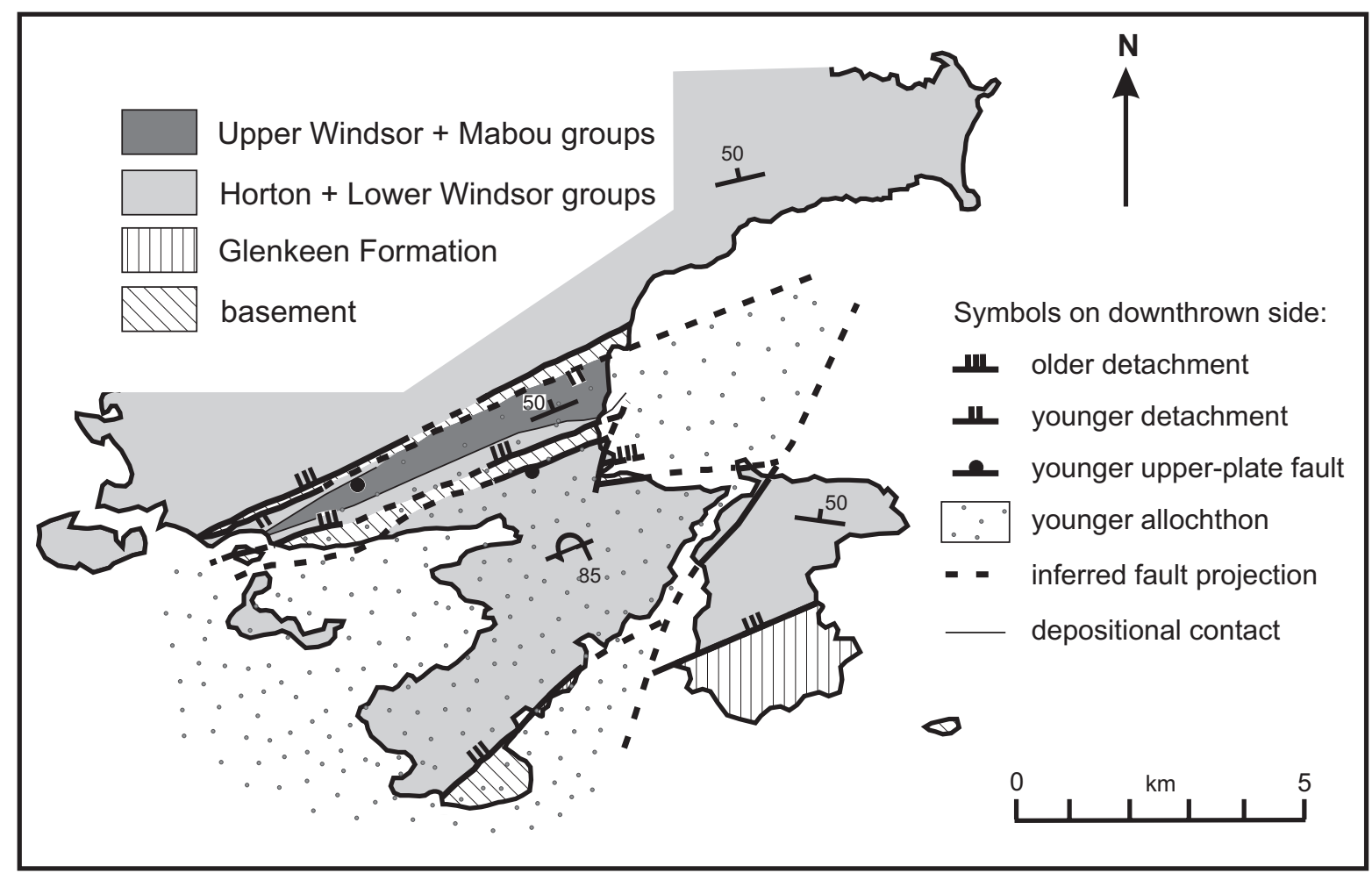

Fig. 14 Tectonic map of the southeastern part of Isle Madame, showing extensional features. The entire area shown belongs to an older extensional allochthon of Horton-Lower Windsor Group age; the area patterned as "younger allochthon" has been reextended and further rotated, such that features of the older allochthon have been up-ended, as described in the text. 
faults, even in transpressional settings, is widely reported elsewhere, associated with releasing bends of bounding faults (Bradley 1982; Mann et al. 1983) and with unravelling escape structures (Mann 1997). The basins reportedly include pullapart basins, transform-normal extensional basins, and opening escape triangles.

Within transtensional basins, faults commonly show dipslip movement (Aksu et al. 2000), especially on structures oblique to master bounding faults. The latter clearly have an older history related to transcurrent movement, but as basin-bounding faults they acquire a dip-slip component as an overprint. They also become listric and semi-ductile at depth as reported by Aksu et al. (2000). Listric faults generate dips in subsiding basin fill. Sub-basins may be separated by narrow horsts outlined by faults of the negative flower structure type. The resulting geometry is similar to that of purely extensional basins, even to the predominance of dip-slip movement on internal faults. Indeed, much of the literature on extensional tectonics has actually come from transtensional settings (reviewed by Dickinson 2002). Where master bounding faults with transcurrent histories are not exposed, it may be difficult to discern a difference between purely extensional and transtensional basins. No such faults are obviously exposed in the Isle Madame area, although the Lennox Passage Fault (Fig. 2) is a candidate. However, the fault rocks described here that are interpreted to represent listric detachments of the first stage of extension may themselves represent the dissected remnants of original bounding faults no longer exposed as continuous features. This possibility is consistent with horizontal and oblique slickenlines locally observed in the fault rocks (in contrast to dip-slip slickenlines predominant in the basin fill). If a pull-apart basin is the appropriate model, the fault rocks presumably represent its northern margin because tectonic transport was north to south.

Perhaps the complex history of Isle Madame extension is fortuitous; if extension had not been multi-stage we would have been unable to see up-ended deeper elements of a transtensional basin. The next challenge as we see it is to use details of the Isle Madame geology as a tool to elucidate larger regional questions. For example, elsewhere in the Maritimes, transtensional basins are of the same age, but have been described as half-grabens based on shallow-level exposures. Can Isle Madame inform us about the deeper roots of some of these basins? And if so, do these integrated basin geometries have implications for the kinematics of basin formation?

\section{CONCLUSIONS}

The thick conglomerate-dominated successions of Isle Madame are the sedimentary consequences of two periods of lower Carboniferous extension. Deposition was apparently in transtensional basins formed along the Meguma-Avalon terrane boundary. The appreciable dips of the sedimentary succes- (a)

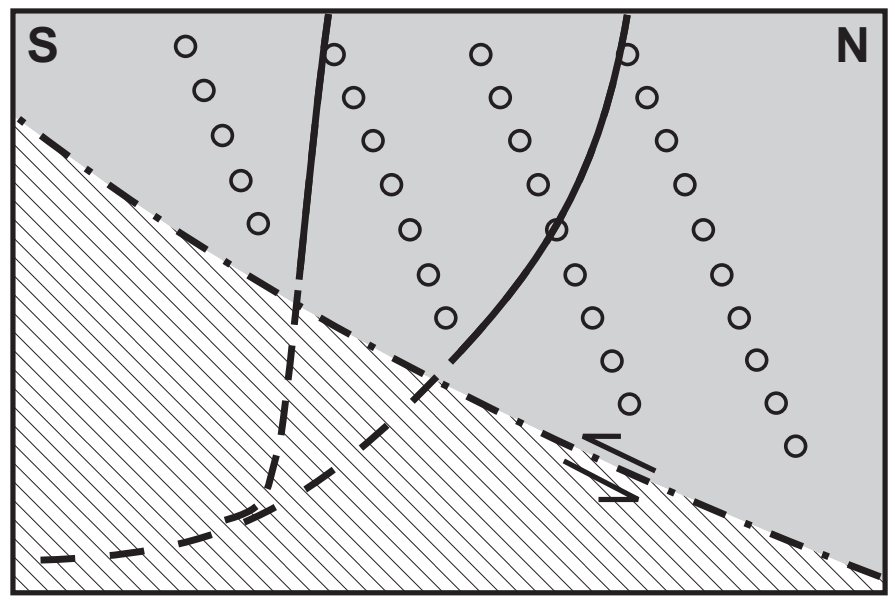

(b)

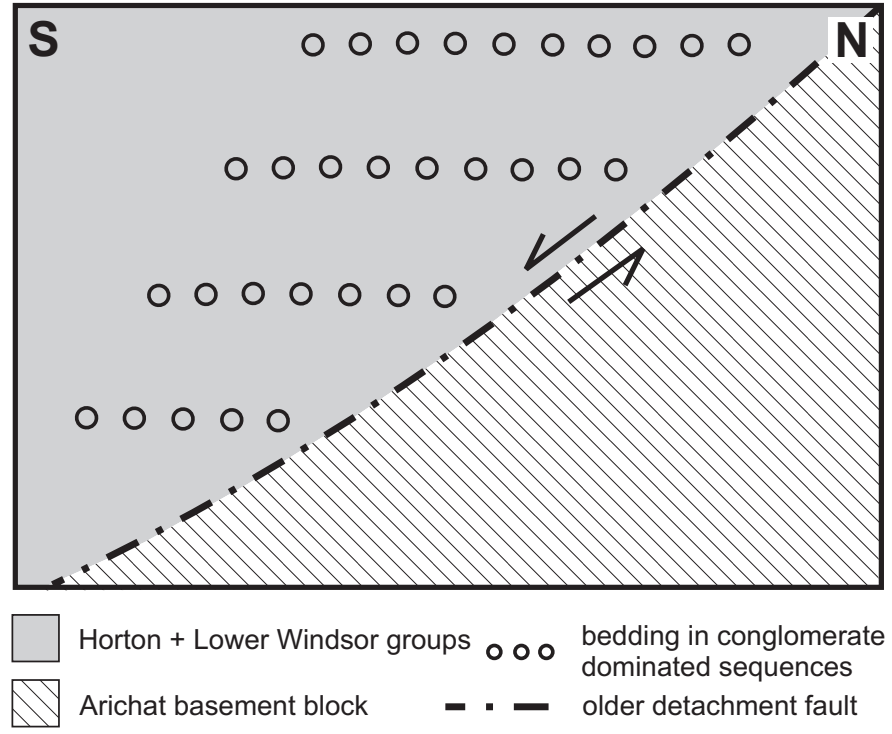

Fig. 15 Reconstruction (based on cross-section of Figure 13, inset) of Arichat and Shaw Point-Irish Point basement belts: a) section prior to second-stage detachment (dashed structures represent second-stage faults that have not yet moved; note that apparent basement uplift to the south at this stage has reversed the dip of the first-stage detachment); b) fully restored section (flat bedding) showing conglomerate accumulation against active high-angle fault cutting basement.

sions result from downfaulting on listric faults. The long narrow belts of basement rocks and associated fault rocks record the juxtaposition of different crustal levels along detachment faults formed during the first period of extension and up-ended by the second. The two-stage extension has exposed relations that may be typical of deeper levels of half-grabens of the Maritimes Basin. 


\section{ACKNOWLEDGEMENTS}

The work of Barr in the Isle Madame area was funded by Natural Science and Engineering research grants. We thank Chris White for his detailed mapping in the area which formed the basis for much of this study, and Peter Giles for his subsequent mapping which enabled further understanding of the geological problems. Force was assisted in the field by his wife Jane and by Jesse Williams. Christa Pufahl and Heather Wolczanski assisted with drafting of the illustrations for this paper. We thank journal reviewers Nick Culshaw and John Waldron, as well as editor Rob Fensome, for their helpful comments which improved the clarity of the manuscript.

\section{REFERENCES}

Aksu, A.E., Calon, T.J., Hiscott, R.N., \& Yasar, D. 2000. Anatomy of the North Anatolian fault zone in the Marmara Sea, western Turkey: extensional basins above a continental transform. GSA Today, 10, pp. 3-7.

Barr, S.M., \& Peterson, K. 1998. Field relations and petrology of the Fisset Brook Formation in the Cheticamp area, western Cape Breton Island, Nova Scotia. Atlantic Geology, 34, pp. 121-132.

Barr, S.M., O’ReILly, G.A., \& O'BeIrne, A.M. 1982. Geology and geochemistry of selected granitoid plutons of Cape Breton Island. Nova Scotia Department of Mines and Energy, Paper 82-1, $177 \mathrm{p}$.

Barr, S.M., White, C.E., \& Graves, M. 1992. Meguma terrane in southern Cape Breton Island? Atlantic Geology, 28, p. 94.

Barr, S.M., Grammatikopoulos, A.L., \& Dunning, G.R. 1994. Early Carboniferous gabbro and basalt in the St. Peters area, southern Cape Breton Island, Nova Scotia. Atlantic Geology, 30, pp. 247-258.

Barr, S.M., Macdonald, A.S., ARnotT, A.A., \& Dunning, G.R. 1995. The Fisset Brook Formation in the Lake Ainslie Gillanders Mountain area, Cape Breton Island, Nova Scotia. Atlantic Geology, 31, pp. 127-139.

BeLt, E.S. 1968. Post-Acadian rifts and related facies, eastern Canada. In Studies of Appalachian geology. Edited by E. Zen and others. Wiley-Interscience, New York, pp. 95-113.

BoeHnER, R.C. 1992. An overview of the role of evaporates in the structural development of Carboniferous basins in Nova Scotia. In Nova Scotia Department of Natural Resources, Minerals and Energy Branch, Report of Activities 1991. Edited by D.R. MacDonald. Report 92-1, pp. 39-56.

Boucot, A.J., LANDing, E., Boyce, W.D., BArR, S.M., \& White, C.E. 2006. Provenance of fossiliferous clasts in Carboniferous conglomerate, Isle Madame, southern Cape Breton Island, Nova Scotia. Canadian Journal of Earth Sciences, 43, pp. 295-302.

BradLEY, D.C. 1982. Subsidence in late Paleozoic basins in the northern Appalachians. Tectonics, 1, pp. 1015-1037.
Calder, J.H. 1998. The Carboniferous evolution of Nova Scotia. In Lyell: the past is the key to the present. Edited by D.J. Blundell and A.C. Scott. Geological Society of London, Special Publication 143, pp. 261-302.

Cormier, R.F. 1980. New rubidium-strontium ages in Nova Scotia. Nova Scotia Department of Mines and Energy, Mineral Resources Division, Report of Activities 80-1, pp. 223-234.

Cormier, C.F.M., Barr, S.M., \& DunNing, G.R. 1995. Geological setting and petrochemistry of early Middle Devonian volcanic and gabbroic rocks in the Guysborough area, Nova Scotia. Atlantic Geology, 31, pp. 153-166.

Cox, D. P, \& ForCE, E.R. IN PRESS. The Ajo mining district, Pima County, Arizona: evidence for middle Tertiary detachment faulting, plutonism, volcanism, and hydrothermal alteration. United States Geological Survey Bulletin.

DAvis, G.H. 1987. A shear-zone model for the structural evolution of metamorphic core complexes in southeastern Arizona. In Continental extensional tectonics. Edited by M.P. Coward, J.F. Dewey, and P.L. Hancock. Geological Society of London, Special Publication 28, pp. 247-266.

Davis, G.H., Constenius, K.N., Dickinson, W.R., RoDRIGUEZ, E. P, \& Cox, L.J. 2004. Fault and fault-rock characteristics associated with Cenozoic extension and core-complex evolution in the Catalina-Rincon region, southeastern Arizona. Geological Society of America Bulletin, 116, pp. 128-141.

Dickinson, W.R. 1991. Tectonic setting of faulted Tertiary strata associated with the Catalina core complex in southern Arizona. Geological Society of America Special Paper 264, $106 \mathrm{p}$.

Dickinson, W.R. 2002. The basin and range province as a composite extensional domain. International Geology Review, 44, pp. 1-38.

Dunning, G.R., Barr, S.M., Giles, P.S., McGregor, D.C., Pe-Piper, G., \& Piper, D.J.W. 2002. Chronology of Devonian to early Carboniferous rifting and igneous activity in southern Magdalen Basin based on U-Pb (zircon) dating. Canadian Journal of Earth Sciences, 39, pp. 1219-1237.

Durling, P., Howells, K., \& Harvey, P. 1995. The near-surface geology of St. Georges Bay, Nova Scotia: implications for the Hollow Fault. Canadian Journal of Earth Sciences, 32, pp. 603-613.

FletCHER, H. 1881. Report on part of the counties of Richmond, Inverness, Guysborough and Antigonish, Nova Scotia. Geological Survey of Canada. $125 \mathrm{p}$.

Geologic Survey of Canada 1964. Aeromagnetic total field, Isle Madame area. Map 19500G

Giles, P.S., Naylor, R.D., Teniere, P.J., White, C.E., Barr, S.M., \& DeMonT, G.J. IN PREss. Geology of Port Hawkesbury (NTS 11F/11, 11F/06, 11F/07, 11F/10). Nova Scotia Department of Natural Resources, Minerals and Energy Branch, Open File Map, scale 1:50,000.

Hagstrum, J.T., Cox, D.P., \& Miller, R.J. 1987. Structural reinterpretation of the Ajo Mining District, Pima County 
Arizona based on paleomagnetic and geochronologic studies. Economic Geology, 82, pp. 1348-1361.

Hamblin, A.R., \& Rust, B.R. 1995. Tectono-sedimentary analysis of alternate-polarity half-graben basin-fill successions: Late Devonian-Early Carboniferous Horton Group, Cape Breton Island, Nova Scotia. Basin Research, 2, pp. 239-256.

Hicks, R.J., Jamieson, R.A., \& Reynolds, P.H. 1999. Detrital and metamorphic ${ }^{40} \mathrm{Ar} /{ }^{39} \mathrm{Ar}$ ages from muscovite and wholerock samples, Meguma Supergroup, southern Nova Scotia. Canadian Journal of Earth Sciences, 36, pp. 23-32.

HowARD, K.A., \& JoHN, B.E. 1987. Crustal extension along a rooted system of imbricate low-angle faults: Colorado extensional corridor, California and Arizona. In Continental extensional tectonics. Edited by M.P. Coward, J.F. Dewey, and P.L. Hancock. Geological Society of London, Special Publication 28, pp. 299-312.

KePPIE,J.D. 1982. The Minas Geofracture. In Major structural zones and faults of the northern Appalachians. Edited by $\mathrm{P}$. St-Julien and J. Beland, Geological Association of Canada, Special Paper 24, pp. 263-280.

LEEDER, M.R., \& GAWTHORPE, R.L. 1987. Sedimentary models for extensional tilt-block/half graben basins. In Continental extensional tectonics. Edited by M.P. Coward, J.F. Dewey, and P.L. Hancock. Geological Society of London, Special Publication 28, pp. 139-152.

Lister, G.S., \& DAVIs, G.A. 1989. The origin of metamorphic core complexes and detachment faults formed during Tertiary continental extension in the northern Colorado River region, U.S.A. Journal of Structural Geology, 11, pp. 65-94.

LYNCH, G. 2001. Structural denudation of Silurian-Devonian high-grade metamorphic rocks and post-orogenic detachment faulting in the Maritimes basin, northern Nova Scotia. Geological Survey of Canada, Bulletin 558, 64 p.

Lynch, G., \& Giles, P.S. 1995. The Ainslie detachment: a regional flat-lying extensional fault in the Carboniferous evaporitic Maritimes Basin of Nova Scotia, Canada. Canadian Journal of Earth Sciences, 33, pp. 169-181.

Lynch, G., \& Tremblay, C. 1994. Late Devonian-Carboniferous detachment faulting and extensional tectonics in western Cape Breton Island, Nova Scotia, Canada. Tectonophysics, 238, pp. 117-129.

ManN, P. 1997. Model for the formation of large, transtensional basins in zones of tectonic escape. Geology, 25, pp. 211-214.

Mann, P., Hempton, M.R., Bradley, D.C., \& Burke, K. 1983. Development of pull-apart basins. Journal of Geology, 91, pp. 529-554.

McCutcheon, S.R., \& Robinson, P.T. 1987. Geological constraints on the genesis of the Maritimes basin, Atlantic Canada. In Sedimentary basins and basin-forming mechanisms, Edited by C. Beaumont and A.J. Tankard. Canadian Society of Petroleum Geologists, Memoir 12, pp. 287-297.
MurPhy, J.B., \& KeppiE, J.D. 1998. Late Devonian palinspastic reconstruction of the Avalon-Meguma terrane boundary: implications for terrane accretion and basin development in the Appalachian orogen. Tectonophysics, 284, pp. 221-231.

Pe-Piper, G., \& Piper, D.J.W. 1998. Geochemical evolution of Devonian-Carboniferous igneous rocks of the Magdalen Basin, eastern Canada: $\mathrm{Pb}$ - and Nd-isotope evidence for mantle and lower crustal sources. Canadian Journal of Earth Sciences, 35, pp. 201-221.

Reynolds, P.H., Barr, S.M., White, C.E., \& Ténière, P.J. 2004. ${ }^{40} \mathrm{Ar} /{ }^{39} \mathrm{Ar}$ dating in the Lochaber-Mulgrave area, northern mainland Nova Scotia: implications for timing of regional metamorphism and sediment provenance in the Late Devonian-Early Carboniferous Horton Group. Canadian Journal of Earth Sciences, 41, pp. 987-996.

Seranne, M., \& Seguret, M.1987. The Devonian basins of western Norway: tectonics and kinematics of an extending crust. In Continental extensional tectonics. Edited by M.P. Coward, J.F. Dewey, and P.L. Hancock. Geological Society of London, Special Publication 28, pp. 537-548.

SPENCER, J.E., \& REYNolds, S.J. 1989. Middle Tertiary tectonics of Arizona and adjacent areas. In Geologic evolution of Arizona. Edited by J.P. Jenny and S.J. Reynolds. Arizona Geological Society Digest, 17, pp. 539-574.

SPENCER, J.E., \& REYNOLDS, S.J.1991. Tectonics of mid-Tertiary extension along a transect through west-central Arizona. Tectonics, 10, pp. 1204-1221.

Waldron, J.W.F., White, J.C., MacInnes, E., \& Roselli, C.G. 2005. Transpression and transtension along a continental transform fault: Minas fault zone, Nova Scotia. Atlantic Geoscience Society, Special Publication 33, Geological Association of Canada field trip B7 guidebook, $65 \mathrm{p}$.

Webster, T.L., Murphy, J.B., \& Barr, S.M. 1998. Anatomy of a terrane boundary: an intergrated structural, geographic information system, and remote sensing study of the late Paleozoic Avalon-Meguma terrane boundary, mainland Nova Scotia, Canada. Canadian Journal of Earth Sciences, 35 , pp. 787-801.

WeeKs, F.J. 1954. Southeast Cape Breton Island, Nova Scotia. Geological Survey of Canada, Memoir 277, 112p.

Weeks, F.J. 1964. Geology, St. Peters, Richmond County, Cape Breton Island, Nova Scotia. Geological Survey of Canada, Map 1083A, scale 1:63 360.

White, C.E., \& BArr, S.M. 1998. Preliminary geological map of Guysborough, Richmond and Antigonish counties (parts of NTS sheets 11E/08, 11F/05, 11F/06, 11F/10,11F/11, 11F/12 and 11F/15), Nova Scotia, Canada. Nova Scotia Department of Natural Resources, Minerals and Energy Branch, Open File Map 1998-001, scale 1:100 000.

White, C.E., \& BARR, S.M. 1999. Geology of the Guysborough-Mulgrave-L'Ardoise area: a progress report. In Minerals and Energy Branch, Report of Activities 1998. Edited by D.R. MacDonald and K.A. Mills. Nova Scotia Department of Natural Resources, Report ME 1999-1, pp. 105-117. 
White, C.E., Barr, S.M., \& Ketchum, J.W.F. 2003. New age controls on rock units in pre-Carboniferous basement blocks in southwestern Cape Breton Island and adjacent mainland Nova Scotia. In Nova Scotia Department of Natural Resources, Minerals and Energy Branch, Report of Activities 2002. Edited by D.R. MacDonald. Report ME 2003-1, 163-178.
YARNOLD, J.D., \& LOMBARD, J.P. 1989. A facies model for large rock-avalanche deposits formed in dry climates. In Conglomerates in basin analysis. Edited by I. P. Colburn, P. L, Abbott, and J. Minch. Society of Economic Paleontologists and Mineralogists, Pacific Section, 62, pp. 9-31.

Editorial responsibility: Robert A. Fensome 